\title{
Canonical understanding of the sacrifice of Isaac: The influence of the Jewish tradition
}

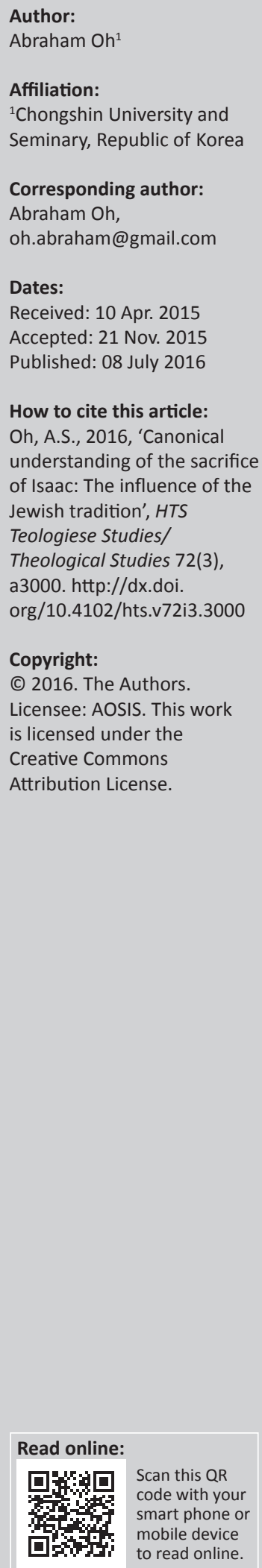

\begin{abstract}
The Aqedah in Jewish tradition is an alleged theology for the sacrifice of Isaac which has an atoning concept and has influenced the atonement theology of the New Testament (NT), but it has not been proved by the NT. The purpose of this article is to investigate all verses in the NT that are alleged to refer to Abraham's offering of Isaac. The reflections of Genesis 22 in the NT verses do not grant atoning power to the sacrifice of Isaac. Abraham's portrait suggests Christ as the Beloved Son, but the vicarious death of Jesus on the Cross is unrelated to Isaac in Genesis 22. Isaac is the type of Christ only in the preparation of death. Jesus as the Tamid lamb (not as the Paschal lamb) refers to Genesis 22 without granting expiation of sin by Isaac. The resurrection motif as well as the promise-fulfilment scheme referring to Genesis 22 also does not validate the Aqedah. Thus, the NT does not assume the Aqedah.
\end{abstract}

\section{Introduction}

The Aqedah is a Jewish understanding of the sacrifice of Isaac (SI) in Genesis 22. Some scholars have argued that the Aqedah has an atoning concept and that it has influenced Jesus' selfunderstanding of his own destiny as well as the Pauline theology of atonement in the New Testament (NT) (Daly 1977:74; Vermes 1961:223). Other scholars have claimed that the Aqedah is rather influenced by Christian theology (Davies \& Chilton 1978:517). This dispute has a long history because it includes two important issues of understanding: the relationship between Judaism and Christianity, as well as the relationship between the Old and the New Testament. ${ }^{1}$

The Aqedah has been developed in Jewish literature granting the power of atonement to Isaac's death. In Jewish literature, Isaac has an active role in Abraham's offering of Isaac. When Abraham announced to Isaac that he is going to be sacrificed, Isaac is described to be willing and determined to be sacrificed as an act of piety. He does not only consent to be sacrificed but also requests to be bound (Fragmentary Tg Gn. 22:10). Abraham even asks God to remember Isaac's willingness as well as his own obedience (Fragmentary Tg Gn. 22:14). God blesses their descendants on the account of Abraham and Isaac especially. Midrashim Mekhilta shows that Isaac even sheds one quarter of blood and his blood is turned into ashes. All of this emphasises the prominent role of Isaac in the story of the SI to grant Isaac an atoning function for Israel (Mekhilta Ex. 12:13; 32:13). According to Vermes, the Aqedah has been developed with the nourishment of the martyrdom theology. Martyrdom has granted benefits to the people of Israel at times of harsh religious persecutions for example under Antiochus Ephiphanes in 167 BC (Vermes 1961:203-204). Consequently, the Aqedah has been considered to be endowed as a sacrifice of atonement with salvation and eternal life to the people of Israel, as well as protection and rescuing from every tribulation of Israel. Isaac seems to function as a messiah in the Aqedah. For this reason, the Aqedah became the paradigm for the suffering of Jesus (Vermes 1961:219-220).

Given that the atonement theology is the essential feature of the Aqedah, it is imperative to determine whether the Aqedah influenced the NT theology. This may require a twofold investigation: firstly, from a historical approach. We need to study how the Aqedah has been formed chronologically, especially in the pre-Christian era. Secondly is a canonical approach. We need to investigate how the NT understands the SI and how its canonical understanding of the SI is different from or related to the Jewish view. This approach will examine how the SI is understood in the Old and the New Testament in a unitive manner. ${ }^{2}$

1.As for the historical survey of the discussion about the Aqedah, see Swetnam (1981:4).

2.Canonical approach may simply be defined as an interpretive strategy that views the canon, the final form of the Old and the New Testament, as the authoritative text and understands the text primarily in the canonical context, that is, in the context of the entire Bible of the Old and the New Testament. Childs 1979:69-83; Sailhamer 1987:307. 
The historical study of the Aqedah has been conducted separately in my other articles (Oh 2014a:5-24). According to my previous studies, the alleged pre-Christian sources such as Jubilees, Pseudo-Jubilees, Philo, 4 Maccabees, Josephus, and Pseudo-Philo do not contain an expiatory function for the SI. ${ }^{3}$ Jubilees does not display the Aqedah because the connection between the SI and Passover is indirect and the SI prefigures the Temple cult only. It is alleged that Isaac's willingness in Pseudo-Jubilees is based on scholarly reconstruction. On Abraham of Philo lacks the binding and willingness of Isaac. This is more significant in terms of allegory rather than in terms of theology. For Philo, the SI cannot be seen as the Passover lamb but the Tamid offering. ${ }^{4}$ In 4 Maccabees, the main subject is the martyrdom and not the Aqedah. Isaac is just one of many martyrs and he was never described to have expiatory power. In fact, his sacrifice was not completed. Josephus does not explicitly mention the expiatory function of the SI because he is not interested in theological matters. Although he mentions Isaac's willingness to be sacrificed, God's reward is not because of Isaac's merit, but to Abraham's. Although Pseudo-Philo sometimes has been considered as the direct mediator between the Jewish and Christian understanding, it does not give any evidence for the atoning power. Because of the uniqueness of the SI in $32: 3$, it is different from the martyrdoms in 2 Maccabees in that the latter may have atoning power. In 40:2, it is not Seila's death but Israel's prayer that brings the victory of Israel. Again, the connection between Seila and Isaac does not provide evidence for atonement. Abraham is rewarded, not Isaac. In 18:5, Abraham's merit is at issue, not Isaac's. The SI has not been completed although the blood of Isaac is mentioned. The above investigation disclosed that the preChristian Jewish literature does not display the Aqedah as it is often alleged.

Thus, it would be an anachronism to regard the Aqedah theology in relation to the atonement theology in the NT. There may be conceptual connections between the post-CE Jewish literature and the NT (Kim 2001). However, it should be verified by a sole investigation of the NT texts to answer how the SI is understood in the NT and whether the NT writers were aware of the Aqedah and alluded to it at the time of their writings. This takes us to the next investigation to examine how the SI is canonically understood in the Old and the New Testament. All the possible NT verses that are related to the SI or Genesis 22 are examined to see how the NT writers understand Genesis $22 .{ }^{5}$

Prior to our next investigation, it should be noted that the word Aqedah is derived from the Hebrew עקד, 'to bind'. The word Aqedah appeared probably after the second century A.D. (Segal 1984:173). It originally referred to a special way of

\section{For Vermes (1961:197), these are the pre-Christian precursors of the Jewish view.}

4.The Tamid offering is the one offered in the morning and evening every day

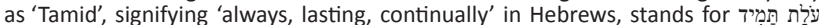
(Nm. 28:6)

5.It should be noted that the atonement theology in general or in particular (the background or ored that the atonement theology in general or in particular (the theology) is not our present purpose, but could be another topic of independent theology) is binding of the Tamid lamb, which was offered to the altar every day according to Mishna. At first this means Abraham's act of offering Isaac. It also referred to the holistic event described in Genesis 22. But it carries some theological implications in Jewish tradition, namely the Aqedah. Thus, we need to distinguish the SI as presented in Genesis 22 from the theologically enriched interpretation in the Jewish tradition. The term SI is used in a neutral sense (i.e. Genesis account per se) in this paper. But the term Aqedah is not. It is the Jewish understanding of the SI and it includes the concept of atoning power of the SI at the later stage (Davies \& Chilton 1978:514-515; Fitzmyer 2002:211; Spiegel 1979:xix-xx; Swetnam 1981:75).

\section{The sacrifice of Isaac in Genesis and the Old Testament}

The story of the SI in Genesis 22 is posited, and should be understood, in the literary context of Abraham's cycle $(\mathrm{Gn}$. 11:28-25:18). The whole cycle is pivoted by a theme of promise (12:1-4; chs. $15 \& 17 ; 22: 16-18)$. The canonical function of the introductory comment in 22:1 ('after these things') makes readers see the episode of Genesis 22 in the light of this cycle. The command of God in 22:1 was intended to test Abraham's faith in God. However, the story of the SI (Gn. 22) should be understood in the context of promise and fulfilment. Childs (1992:401) observed that this command is obviously self-contradictory to God's promise. God promised Abraham to make a nation through his son. But the SI threatens this very promise between God and Abraham. This episode shows that God himself intervened in the actions of Abraham obeying his command and that he restored and kept the promise by providing a substitute for the son to be sacrificed. Thus, the introductory comment on the purpose of the story is maintained throughout.

In the wider context of the Old Testament (OT), the story of the SI is related to the cult as it can be seen in Leviticus and in 2 Chronicles 3:1. In the light of 2 Chronicles 3:1, this episode is a prefiguration of the Temple sacrifices because the verse identifies the Temple Mount with Moriah and it requires readers to link the story of Genesis 22 with the Temple cult. (Frances Young [1994:40] understands this connection as a 'typology of spatial nature'.) The cultic understanding of the SI is reinforced by the common keywords in Genesis 22 and Leviticus such as 'lamb', 'burnt offering', and 'will be seen' (Lev. 9:6, 23). These three words do not appear together anywhere else in the OT, only in Leviticus. This link leads us to acknowledge that the personal experience of Abraham is associated with the public service of Israel and the SI in turn could function for Israel as a model of sacrifice (Childs 1992:394). For Childs (1992:394), because of this connection, the canonical shape of a larger scope (i.e. Pentateuch) suggests for us to understand the whole cultic law of Leviticus in the light of revelatory event in Genesis 22: God showed his will to Abraham on how to fear God and how to serve him. Wenham (1995:95) also contends that Abraham's sacrifice has a continuous efficacy 
in functioning as a paradigm of sacrifice for the sacrifices thereafter. The fundamental principle of Israel's rituals such as God-appointed sacrifice, place, and procedure, etc. can be read from Genesis 22 (Wenham 1995:102). In short, the SI in Genesis 22 is the prefiguration of the cultic system in Leviticus and the Historical Books.

\section{The sacrifice of Isaac in the New Testament}

Next we will examine the verses in the NT to see how this story of the SI is related to, and fulfilled in, the NT. A possible 'typological' understanding may be related to the Aqedah. To this end, we will examine the verses that are alleged to be influenced by the Aqedah referring to the SI in Genesis 22. The SI can be thematically grouped according to the theological features of Jesus Christ.

\section{Jesus as the Beloved son}

It has been suggested that Romans 8:32 typologically relates

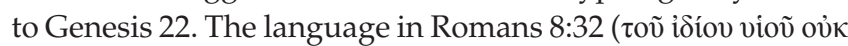

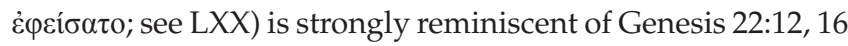

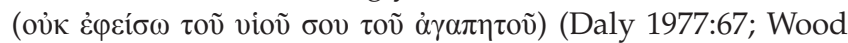
1968:598). If the death of Christ on the cross is the background of Paul's thought in Romans 8:32, the images of the two events [the cross event and the SI] are mutually evocative because the act of Abraham sacrificing his son is mirrored in the act of God handing over his Son (Childs 1992:396;

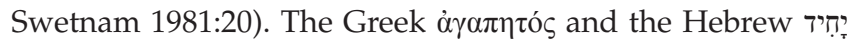
do not correspond in a one-to-one manner (Davies \& Chilton 1978:531; Swetnam 1981:21). ${ }^{6}$ Genesis 22 provides a typical model of a loving relationship between father and son in the OT, because the LXX may have been used instead of the Masoretic as the received text in Paul's days. ${ }^{7}$ Furthermore, Jesus in many ways is parallel to Isaac in Genesis 22: Isaac carried the wood as Jesus bore the wooden Cross (Schoeps 1946:387); Isaac obeyed his father as Jesus did; Isaac was prepared to be sacrificed on the altar as Jesus was to be crucified on the cross; Jewish tradition claims that Isaac died and was resurrected as Jesus did. Moberly (2001:133) opines, '[W]hether or not Paul intended an allusion to Genesis 22 is unclear, but Paul's language naturally lends itself to a typological parallel between Abraham and Isaac and God the Father and God the Son'.

However, the connection between Jesus and Isaac in the two places has been questioned because the link between them is only indirect and implicit. Christ and Isaac are not the main characters, yet passive in these two parallel stories. The essence of these two stories is the fathers' action withholding not and giving up their sons giving up their sons. This

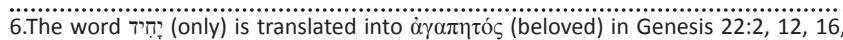

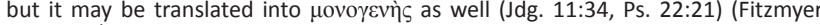
2002:213).

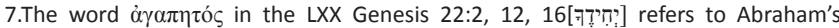
beloved only son Isaac. In Psalm. 60:7[LXX 59:7; Eng 60:5] and 108:7[LXX 107:7; Eng 108:6], and possibly in Psalm 127:2[LXX 126:2; Eng. 127:2], as the translation of 108:6], and possibly in Psalm 127:2 [XX $126: 2$; Eng. 127:2], as the translation of and Jeremiah 38:20 as well, it is the covenant people. In Amos 8:10, Zecharia 12:10 and Jeremiah 6:26[יחיד], it signifies a father-only son relationship in general and in

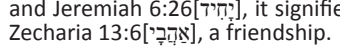

indicates a major correspondence between Abraham and God, not between Isaac and Jesus, ${ }^{8}$ because Isaac did not die, as he avoided a sacrificial death (Davies 1982:655-656). Dahl (1969:18) refutes a typological relationship between the binding of Isaac and the death of Christ, claiming that Romans 8:32a relates to Abraham's action rather than Isaac's suffering. Therefore, Christ can be related to Isaac only through the portrait of the Father not withholding and giving up his only beloved Son (Davies \& Chilton 1978:530).

For the same reason, 2 Samuel 21:1-14, rather than Genesis 22 , has been suggested to lie behind Romans 8:32. Schwartz (1983:264) questions the general observation that Romans 8:32 alludes to Genesis 22. According to Schwartz, the parallel between the Aqedah and the death of Christ is very weak: Isaac did not die and his death was not for the sake of others. Schwartz suggests instead that Paul alludes in Romans 8:32 to 2 Samuel 21:1-14. The two texts have closer parallels than Romans 8:32 and Genesis 22. David and God, someone else's son and His own son, 'spared' and 'did not spare' are parallel. Furthermore, in 2 Samuel 21:1-14, people were given and actually killed by hanging or crucifixion for the sake of the people (Schwartz 1983:264-266). Schwartz's observation of the analogical similarity between Romans 8:32 and 2 Samuel 21 cannot be denied. Nevertheless, the analogy may not necessarily dismiss the possible connection between Romans 8 and Genesis 22, because God, not Christ, is the main subject in Paul's thought in Romans 8:32. His argument that the redemption of Christ on the cross is based on 2 Samuel 21:1-14 seems dubious. The cross event is not so much a theological device by Paul based on a haphazard passage of the OT; it is rather the fulfilment of God's plan, which has been revealed since Genesis 3:15. ${ }^{9}$ Likewise, both of the two verses may be suggestive for Romans 8:32. However, Genesis 22 seems preferable as the background of Romans 8:32 because God's beloved Son was sacrificed on the Cross to fulfil his promise (Gn. 12:1-4; 15:1-21; 17:1-27; 22:16-18) which was given to Abraham as to his 'seed' (Gl. 3:16). Although the two events in 2 Samuel 21 and Romans $8: 32$ are in a simple analogical relation, Genesis 22 is related to Romans 8:32 in the historical context of God's plan of salvation. The connection between the two events of Genesis 22 and Romans 8:32 reflects the fulfilment of promise. Therefore, Genesis 22 prefigures the image of God in Romans 8:32 as Christ being the Beloved Son.

This image of the Father-Son relation recurs in the NT, especially in the baptism and transfiguration scenes of Christ. According to Richardson (1958:180), the language

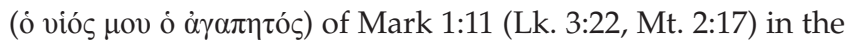
baptism scene of Jesus is a 'clear echo' of Genesis 22:16. Daly (1977:68) also observed that the theophanic motif of the voice from heaven may also be a resonance with Genesis 22 in

8.For Childs (1992:402), the correspondence between Genesis 22 and Romans belongs to Abraham's act and not Isaac's suffering.

9. Hengstenberg $(1956: 11,28)$ and Heinisch $(1956: 27)$ understand Genesis 3:15 as a prophecy, which is fulfilled with Christ because of 'the seed'. Also see below about
the seed. 
Mark 1:11, 9:7 and their parallels. ${ }^{10}$ In brief, $\alpha \gamma \alpha \pi \eta \tau$ ó $\varsigma$ in the baptism narrative and the transfiguration report, as well as in Romans 8:32 may refer to Abraham's relation to his beloved son, typologically signifying God as the Father sacrificing his own Son and Christ as the Beloved Son.

\section{Vicarious death on the Cross}

Although the portrait of Abraham as loving father is mirrored in the NT, this does not necessarily suggest that the vicarious death of Jesus on the Cross is mirrored in the SI. Schoeps (1946:391) claims that the expiatory power of the sacrificial death of Christ is built on the Aqedah, because Romans 8:32 is a Christological reinterpretation of Genesis 22 (Schoeps 1946:390; author's own italics). He (1946:391) also thinks that the blood of Christ justifying Christians in Romans 5:9 is the influence of the Aqedah. However, because the SI does not mention 'the blood' of Isaac, Romans 5:9 cannot refer to the SI. Although Genesis 22 may prefigure Christ as the promised 'seed' of not only Abraham but also Adam (Gn. 3:15), ${ }^{11}$ the atonement is not necessarily based on the SI, because Isaac did not die. Furthermore, the proper understanding of atonement in the Aqedah was not established in the pre-Christian era as shown in my other papers (see the summary above). ${ }^{12}$ Schoeps' view is anachronistic if he is not confused between the SI per se and the Aqedah. Because Christ and Isaac are passive in Romans 8:32 and Genesis 22, Romans 8:32 cannot be connected to Isaac's death or to the Aqedah (Davies \& Chilton 1978:532). Isaac is not a type of Christ in respect to his sacrificial death. Isaac is only prefiguring Christ in bearing wood and ascending on the altar in obedience to his father. He actually did not die; a replaced ram died instead. Isaac was saved by the ram's death on behalf of him. Therefore, Isaac is rather a type of Christian who is saved by the sacrifice of Christ. Romans 9:7-8 understands Isaac as a type of Christian as the children of promise. Isaac-Christian typology is established as this is also evidenced in Galatians 4:28 (Schoeps 1946:386; Wood 1968:589). It was the ram that was actually slaughtered instead of Isaac. The ram-Christ typology is suggested with respect to the sacrificial death in Genesis 22. According to Wilken (1976:64), Melito of Sardis identified as many parallels as possible between Isaac and Jesus. But he emphasised that Jesus died but Isaac did not. He claimed that Isaac was 'a type of Christ who was going to suffer'. According to Davies (1982:655-657), the parallels 'furnished a type of Christ only in respect of the preparation for death' in Melito. In other words, the suffering Christ was the New Tamid, not the New Isaac.

For Vermes (1961:222), Mark 1:11 displays the Jewish association of the Aqedah (Gn. 22:16) with the Servant

10. Matthew $12: 18$ and Mark 12:6 may also be related to the $\mathrm{LXX}$ of Genesis 22 due to $\dot{\alpha} \gamma \alpha \pi \eta \tau$ tóc. Abba Father in Mark 14:36 is also related to the story of Isaac in Genesis 22 (Grassi 1982:449-458).

11.Irenaeus, Luther, Delitzsch and König interpreted Genesis 3:15 Christologically (Herrmann 1983:63-69), while Westermann (1984:261) and von Rad (1961:90) considered that the Christological interpretation is not supported by the text.

12.See also Davies and Chilton (1978:540). motif (Is. 42:1). ${ }^{13} \mathrm{He}(1961: 223)$ also claimed that Markan kerygma is influenced by the pre-Christian Jewish Aqedah theme. However, the word $\alpha \gamma \alpha \pi \eta \tau$ ó $\varsigma$ in the baptism and transfiguration scenes does not necessarily show that the SI has atoning power. ${ }^{14}$ The association of Genesis 22 and the servant theme in Mark 1:11 is not attested as the preChristian Jewish tradition although it may be obvious at least in the third century as in Targ. Job 3:18, in which Isaac is expressly called 'the servant of YHWH' (Kim 2001:132). For Daly (1977:67), the word $\pi \alpha \rho \alpha \delta i \delta \omega \mu$ in Romans 8:32, Galatians 2:20, and Ephesians 5:2, 25 and the word $\delta i \delta \omega \mu \mathrm{u}$ in Galatians 1:4, Titus 2:14, and 1 Timothy 2:6 express the self-immolation of Christ, which recalls that of Isaac as portrayed in the Palestine targums. However, $\pi \alpha \rho \alpha \delta i \delta \omega \mu$ ı or $\delta i \delta \omega \mu$ does not occur in the LXX Genesis 22, so they cannot refer to the SI. The picture of Jesus delivering himself to death through obedience is primarily based on the Fourth Servant Song, as this is linked with Genesis 22 in Mark 1:11 (Swetnam 1981:13). The atonement of Christ is not so much based on the Aqedah theology as on Jesus' own teaching as he identified himself with the servant figure in Luke 4:18-19 (Oh 2014b:124-132). The prefiguration of the sacrifice of Christ in the substitute lamb in Genesis 22 does not grant the concept of redemption to the image of Isaac in Genesis 22. ${ }^{15}$ Consequently, the vicarious death of Christ is neither found in the portrait of Isaac, nor influenced by the Aqedah. The Aqedah may be influenced by the atonement theology of Christ that is not included in the SI as Davies and Chilton (1978:538) argued.

\section{Jesus as the Paschal or Tamid Lamb}

Jesus as the Paschal Lamb has been suggested to be an allusion to Genesis 22 especially in the Gospel of John. Wood (1968:586), following C. H. Dodd, argues that in John 1:29 the Lamb of God refers to Isaac of the Aqedah, because for him the Lamb of God is the association of the Passover Lamb and the Suffering Servant. ${ }^{16}$ As Grigsby (1982:54) contested, John portrays Jesus as the Paschal Lamb in his gospel, e.g. in John 1:29, 19:14, 29 and 36. ${ }^{17}$ However, Genesis 22 does not support the connection between Isaac and Passover lamb, because the binding in Genesis 22 should be associated with Tamid, as Davies (1982:60-62) attested. So these verses in John do not refer to Genesis 22. Because the pre-Christian Passover connection of the SI is not warranted, ${ }^{18}$ these verses do not

13.Vermes rejects that Mark 1:11 is an association with Psalm 2:7 and Isaiah 42:1, without providing any specific reasons. Wood (1968:586) follows Vermes.

14.Also see Davies and Chilton (1978:531).

15.This rejects the alleged Aqedah connection of 1 Peter 1:19-20 by Daly (1977:73).

16.Also for Vermes (1961:225). 1 Corinthians 5:7, Christ our Passover is sacrificed for us, is the influence of the Aqedah for Schoeps (1946:391).

17.In 1:29, Christ is directly called as 'lamb', appearing later as well (John 6:45-46 19:14, 29, 36), and slain (5:6, 9). (He also considers the Suffering Servant in Isaiah 53 as the possible model of Jesus.) In 19:14, Christ's death is connected to the Passover, which intentionally presents John's theology on Christ as the Paschal Lamb (p. 55). In 19:29, the hyssop to carry the sponge with vinegar to Jesus is reminiscent of Exodus 12:22 (p. 57) In 19:36, the unbroken bones are also an allusion to the Pascal Exodus $12: 22$ (p. 57) Nm 9:12, p. 58). Therefore, Jesus typology in those passages.
Jame

18. The Passover connection of the $\mathrm{SI}$ is only indirect in Jubilees, since it is not an explicit reference but an inference from the data because Abraham was called in explicit reference but an inference from the data because Abraham was called in
the 12th Nissan, which may imply the SI occurring on the 15th Nissan, that is, the day of Passover. Also see my other article. 
refer to the Aqedah or even to the SI. ${ }^{19}$ Furthermore, in Genesis 22, Isaac is not identified with, but substituted by, the lamb.

John may still capture the portrait of Isaac in other places. Swetnam (1981:20) perceives an allusion to Genesis 22 in John 3:16. ${ }^{20}$ The language 'only begotten Son' or 'beloved' in John 3:16 probably refers to the image of Abraham in Genesis 22 (see above). Jesus as the Lamb of God may be the fulfilment of Genesis 22:8 and 13. ${ }^{21}$ However, this is not the Isaac-Jesus typology, but the lamb-Christ typology. Grigsby (1982:59) contends that Christ in the Gospel of John may be the Isaac figure, as he is related to the Aqedah motif, although he admits that the Lamb of God in 1:29 is not the Isaac figure of the Aqedah theology. For Grigsby (1982:60), 'Isaac's sacrificial death was both expiatory and anticipatory of the Paschal sacrifice', and 3:16 is the 'fullest Johannine expression of the Christian Aqedah' as Christ's death is the sacrifice of the new Isaac. ${ }^{22}$ It should be cautious to operate from the presumption of the influence by the Aqedah theology because it has not been attested yet. The SI is alluded to in Christ bearing his own Cross on Calvary in 19:17 but Isaac did not die. Unlike the death of Christ, the expiatory character of the SI is not warranted. Because of the replacement with a ram, this ram itself is the type of Christ.

The connection between Jesus and Isaac in John 3:16 does not contain atoning value because Isaac cannot be linked to the Passover lamb in John 1:26 in which the Lamb of God carries the sins of men. Jesus as the Paschal Lamb does not refer to the SI, although Jesus as the Tamid Lamb may refer to Genesis 22. However, not Isaac, but the replaced lamb is the prefiguration of the dying Christ. The connection of John to Genesis 22 does not grant Isaac an atoning power.

\section{Resurrection}

In Genesis 22, Isaac is bound on the altar and then released according to the divine intervention, which may be analogically referred to in the NT. Hebrews 11:17-19 portrays the faith of Abraham believing God to raise Isaac even if he gets killed in the sacrifice. In this passage, there may be a conceptual connection between the resurrection of Christ and Isaac's rescue by God's intervention in Genesis 22. The resurrection motif in the passage (referring specifically to Gn. $22: 5,8$ ) can be considered as the Isaac-Christ typology (Wood 1968:588). However, Hebrews 11:17-19 does not imply that the SI was completed. This contradicts to Daly (1977:67) because he claimed that the sacrifice was 'completed' ( $\pi \rho \circ \sigma \varepsilon v \eta \dot{v o \chi \varepsilon v)}$ and thus this passage is a certain reference to the Aqedah. The outward action was not completed although the inward action

19.For Daly (1977:72), John 19:14 could well signify an allusion to the Aqedah, not only to the Passover. For Swetnam (1981:13), in John 18:28, 19:36, the Passover lamb suggests a background of the Aqedah.

20.For Daly (1977:73) as well, John 3:16 is a probable reference to the Aqedah.

21.For Vermes (1961:225), 'St. John is asserting that the new relationship of God and man in Christ (the new covenant) is based upon the fulfilment of the promise contained in Genesis 22:8, that God would provide the Lamb which would make atonement for universal sin'. Also see Richardson (1958:228).

22. He (1982:60) quotes from Braun for three correspondences between John 3:16 and Genesis 22. may be so (Davies \& Chilton 1978:529). Besides, as Swetnam (1981:13) observed, testing Abraham is prominent in Hebrews 11:17-19, but not Isaac. After all, the Isaac figure does not involve expiatory meaning in this passage. The resurrection motif in the passage is only analogical.

Romans 4:16-25 also portrays Abraham's faith in God to raise the dead. For Wood (1968:588), this is a resurrection motif, so it is an Isaac typology. Daly (1977:72) also considers that the act of Abraham is the 'meritoriously redemptive act par excellence' and the resurrection motif included strongly points to the Aqedah. However, the resurrection concept per se does not refer to the Aqedah (Davies \& Chilton 1978:532). The overall message of the Romans passage is justification by faith as it was in Abraham. Romans 4:17 does not refer to the real resurrection but indicates the faith in resurrection. Therefore, the resurrection motif does not support the expiatory power of Isaac in Genesis 22.

The phrase 'on the third day' as a resurrection motif in 1 Corinthians 15:4 may also be an allusion to Genesis 22:4. The phrase of Genesis 22 may also be referred to in Hosea $6: 2-3$, where God would raise his people on the third day (Gill, Genesis 22). For Wood (1968:588), it is also referred to in Leviticus 23:10-11. The ritual of consecration in this passage of Leviticus is analogically applied in 1 Corinthians 15:20, where Christ is the first fruit of people who sleep. Contrary to Daly (1977:71), however, it does not necessarily refer to the Aqedah because it does not grant atoning power. In conclusion, several passages that are typologically connected to Genesis 22 in the resurrection motif do not assume the real death and resurrection of Isaac nor the expiatory function of the SI either.

\section{Promise and fulfilment}

In Genesis 22:16-17, God blesses Abraham for his obedience and declares a reward as to his seed to be fulfilled in the NT. For Dahl (1969:25), the atonement of Christ's death is given as 'adequate reward' for the Aqedah. He used two passages to support his claim. Firstly, Galatians 3:13-14 alludes to Genesis 22. Galatians 3:14a is the paraphrase of Genesis 22:18, as 'in Christ Jesus' being a replacement of 'in your offspring' in Genesis 22:18 (Dahl 1969:23). The idea of substitution in $3: 13$ is related to that in Genesis 22. 'A man hanging upon a tree' (3:13) resonances with 'a ram caught in a thicket' (Gen. 22:13), which implies that the crucified Christ is the antitype of the ram.

However, this connection between Galatians 3:13-14 and Genesis 22 seems too speculative and indirect at best. Although Christ is the fulfilment of the 'seed', the phrase does not evidence the direct connection to Genesis 22, but to the Abraham cycle in general. The blessing (v. 14) has been given as promise to Abraham throughout the Abraham cycle, not being limited to Genesis 22. The idea of substitution (v. 13) is more related to Isaiah 53. The connection between tree and thicket is too imaginative - in fact the tree refers to Deuteronomy 21:23. Although Galatians 3:13-14 portrays the 
atonement of Christ, this is not given as reward for the Aqedah. The Galatians passage does not give evidence for the atoning power of the SI, and the blessing fulfilled in Christ is the fulfilment of the long-standing promise.

Dahl (1969:24) gives another evidence for the atonement as reward given to Abraham. He claims that Romans 3:24-25

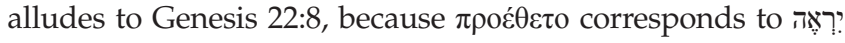
and 'in your offspring' is paraphrased into 'in Christ Jesus' and refers to 4 Maccabees 17:22. The lamb prepared as a burnt offering in Genesis 22:8 is fulfilled at the Cross of the Messiah. However, the direct link of Romans 3:24-25 to the SI is not warranted, and neither is the passage an appropriation of the Aqedah or martyrdom theology. According to Dahl (1969:25), the passage 'to declare his righteousness' (Rom 3:25) signifies in the light of Romans 3:4 ('That thou mayest be justified in Thy words') that '[p]roviding for an expiation, God manifested His righteousness, i.e. He vindicated Himself as being righteous and doing what He had said'. Thus, Dahl concluded that the manifestation of God's righteousness is the fulfilment of his oath in Genesis 22:16-18, and thus he considered 'the Atonement as reward for the Akedah' (1969:25). However, Dahl's conclusion lacks clear evidence. The atoning death of Christ may be assumed in v. 25 , but the reference to the SI is unclear. The atoning power refers to the sin offerings of the Day of Atonement (Lev 16:12-19) because of 'blood' and 'propitiation'. According to Dunn (1988:180), i i $\alpha \sigma \tau$ prov is always used as the mercy seat in the LXX Pentateuch, although it may secondarily relate to 4 Maccabees 17:22. Therefore, the passage of Romans 3 cannot be the evidence of the atonement as reward for the Aqedah. The atonement of Christ is more related to the cultic system in the Pentacteuch, as the Greek word may imply (also see section 2 above).

James 2:21-23 mentions Abraham's offering of Isaac. It is sometimes considered to imply that expiation was given as reward in the Aqedah (Daly 1977:67). However, the focus in this passage is Abraham's obedience, not Isaac's self-sacrifice. Furthermore, it cannot be implied that the sacrifice is completed as Daly claimed. Davies and Chilton (1978:530) claimed that this passage does not refer to the Aqedah, because Abraham's faith and works may be exemplary but not unique. ${ }^{23}$ In fact, the focal purport of the passage is that Abraham's behaviour is the real manifestation of his faith of Genesis 15:6. The reward for Abraham's faithful act is a fulfilment and reaffirmation of Genesis 15:6 which has been given by grace (i.e. as promise).

For Wood (1968:587), Hebrews 6:13-14 quotes from Genesis 22:16-17. The phrase 'he swore by himself' in Hebrews 6:13 is parallel to the phrase 'I swear by myself' in Genesis 22:16. But this does not prove that redemption is given as reward for Abraham's merit. The phrase 'Abraham received what was promised' in Hebrews 6:15 refers to the birth of Isaac in Genesis 21. If it is extended to posterity to come and the Messiah, it is in his faith. So, the blessing in the previous verses (6:13-14) does not necessarily refer to the blessing in 23.Also see Swetnam (1981:20).
Genesis 22:16-18 only. Rather it generally refers to all the promises of Genesis 12, 15, 17, and 22 altogether.

For Vermes (1961:221), Acts 3:25-26 is a re-interpretation of Genesis 22:18, so the Aqedah can be observed. But the connection to Genesis 22:18 does not guarantee the expiatory value of the SI, as we have discussed already. The blessing promised in Genesis 22:18 has been pronounced ever since 12:1-3.

All things ( $\tau \grave{\alpha} \pi \alpha ́ v \tau \alpha \dot{\eta} \mu \tilde{v}$ ) in Romans 8:32 are understood as the eschatological inheritance promised to Abraham and his offspring (Dahl 1969:18). The heir of the world in Romans 4:13 may be related to Genesis 22:17-18 (Schwartz 1983:264). These are not only the fulfilment of Genesis 22:17-18 but of the general promise given to Abraham (Gen 13:5, 15:8, 17:8, 26:4). Although God fulfilled his promise of Genesis 22:16-18 in the NT, the fulfilment is not necessarily a reward for Abraham. Rather it is the divine purpose which he long ago promised and fulfilled in the life of Abraham. Christ's atonement is not the reward of merit in Genesis 22, although he himself is the fulfilment of the promise given to Abraham (Gen 12; 15; 17) as well as to Adam (Gen 3:15) because of the link of the 'seed'.

In the context of Genesis 22, the blessing given to Abraham is beyond question the reward for his obedience: it is a reconfirmation of the promise which God had given and continuously affirmed to him before. ${ }^{24}$ As Calvin commented, 'what God had promised to Abraham before Isaac was born, he now again confirms and ratifies'. ${ }^{25}$ For Moberly (2001:320), 'A promise which previously was grounded solely in the will and purpose of Yahweh is transformed so that it is now grounded both in the will of Yahweh and in the obedience of Abraham (emphasis his)'. As it were, Abraham's obedience has been incorporated into the divine promise. The promise in Genesis 22:16-17 is not to be considered solely as the merit of Abraham or even Isaac. Therefore it is difficult to infer that expiation may be given as the reward to the SI as it is alleged in the Aqedah.

\section{Summary and conclusion}

Abraham's story of the SI has prefigured the Cross event in several ways in the NT. The focus should be kept on the father. The image of Abraham loving but sacrificing his son is reflected in Romans 8:32 and the baptism and transfiguration scenes as well as in John 3:16. Isaac's obedience for bearing wood and ascending on the altar may also prefigure bearing to the cross of Christ. However, the vicarious death of Christ on the cross is not prefigured in the image of Isaac because Isaac is entirely passive: it is not clear whether he was or was not willing to be sacrificed in Genesis 22. Isaac was not slaughtered but replaced by the ram for the sacrifice. This ram, not Isaac, is the type of Christ dying on the Cross. The portrait of Isaac is the Tamid lamb, and not the Passover lamb,

24.See discussions in Childs (1992:402) and Wenham (1995:102).

25.Calvin commentary on Genesis 22:1 in http://www.ccel.org/ccel/calvin/calcom01. xxviii.i.html 
so Jesus as the former in the NT may relate to Genesis 22, while Jesus as the latter may not. Isaac is also a type of Christian for two reasons. Firstly, he is saved because of the replacement of the ram - Christians are saved because Jesus replaced them on the Cross. Secondly, the promise of the 'seed' is fulfilled in the Christians. The resurrection of Christ motif in the NT may also relate to Genesis 22. However, the NT does not show that Isaac has actually died and been resurrected. The focus was on Abraham's belief in God to raise the dead. The resurrection motif is related only analogically to Genesis 22 regardless of still being called as typology. In Genesis 22, God's blessing given to Abraham for his obedience may be considered as reward. But this blessing does not grant an expiatory role to Isaac, because it is still based on a long-standing promise as a part of the divine purpose to save his people.

The Isaac-Jesus typology is imperfect or insufficient. Isaac prefigures Christ only in bearing wood and ascending on the altar in obedience as the beloved son. In terms of sacrificial death, the ram prefigures Christ, so the ram-Christ typology is established. Because Isaac is saved as the ram is sacrificed for him instead, he functions as the type of Christians who are saved because of the death of Christ. Hence, Isaac-Christian typology is formed. Abraham's seed is fulfilled both in Christ and Christians. The typological connection between Isaac and Christ may be established especially in the context of salvation history in which Isaac is given as Abraham's seed, i.e. the seed of promise, the one through whom the nations are blessed themselves. Christians are typologically related to the seed in this salvation history. We cannot find any atoning value in the SI per se as presented in Genesis 22. The atoning value of Christ is the fulfilment of the cultic system in Leviticus, especially the sin offerings of the Day of Atonement. This is prefigured in the SI and Isaiah 53 as well. It is not based on the SI or the Aqedah.

The NT does not assume that the SI has atoning power. Its atonement theology has not been influenced by the Aqedah. The SI prefigures the cultic system and the expiatory power which is fulfilled in the death of Christ. If the Aqedah has an expiatory function, it might be a response to the Christian Christology and soteriology influenced by the Isaac-Jesus typology of the early Church because neither the Old nor the New Testament grants atoning power to the SI.

\section{Acknowledgements Competing interests}

The author declares that he has no financial or personal relationships which may have inappropriately influenced him in writing this article.

\section{References}

Calvin, J., Calvin commentary, viewed 01 February 2015 from http://www.ccel.org/ ccel/calvin/calcom01.xxviii.i.html

Childs, B.S., 1979, Introduction to the Old Testament as Scripture, Fortress Press, Philadelphia, PA.

Childs, B.S., 1992, Biblical theology of the Old and New Testaments, SCM Press, London.

Dahl, N.A., 1969, 'The Atonement - An adequate reward for the Akedah? (Rm. 8:32)', in E.E. Ellis and M. Wilcox (eds.), Neotestamentica Et Semitica, pp. 15-29, F.S Matthew Black, Clark, Edinburgh.

Daly, R.J.S.J., 1977, 'The soteriological significance of the sacrifice of Isaac', Catholic Biblical Quarterly 39, 45-75.

Davies, P.R., 1982, 'Martyrdom and redemption: On the development of Isaac typology in the Early Church', Studia Patristica 17, 652-658.

Davies, P.R. \& Chilton, B.D., 1978, 'The aqedah: A revised tradition history', Catholic Biblical Quarterly 40, 514-546.

Dunn, J.D.G., 1988, Romans 1-8, WBC, Word Book Publisher, Dallas, TX.

Fitzmyer, J.A.S.J., 2002, 'The sacrifice of Isaac in Qumran literature', Biblica 83, 211-229. Gill, J., Gill's Commentary, viewed 01 February 2015, from http://gill.biblecommenter. com/genesis/22.htm

Grassi, J.A., 1982, 'Abba, Father (Mark 14:36): Another approach', The Journal of the American Academy of Religion 50, 449-458.

Grigsby, B.H., 1982, 'The Cross as an expiatory sacrifice in the Fourth Gospel', Journal for the Study of the New Testament 15, 51-80.

Heinisch, P., 1956, Christ in prophecy, Liturgical Press, Collegeville, PA.

Hengstenberg, E.W., 1956, Christology of the Old Testament and a commentary on the Messianic predictions, Kregel Publications, Grand Rapids, MI.

Herrmann, S., 1983, 'Das Protoevangelium 1. Mose 3, 15. Ein exegetische Kabinettstück im Prozess der Bibelrevisionen', in S. Meurer (ed.), MB 20. Die Bibel in der Welt, Ulrich Fich zum 60 Geburstag, pp. 63-69, Deutsche Bibelgesellschaft, Stuttgart.

Kim, J., 2001, 'The concept of atonement in Early Rabbinic thought and the New Testament writings', Faculty Publications and Presentation, Paper 248, viewed 01 February 2015, from http://digitalcommons.liberty.edu/lts_fac_pubs/248

Moberly, R.W.L., 2001, The Bible, theology, and faith: A study of Abraham and Jesus, CUP, Cambridge.

Oh, A.S.H., 2014a, 'Early Jewish understanding of the Sacrifice of Isaac', Korea Journa of Christian Studies 93, 5-24.

Oh, A.S.H., 2014b, 'Oh, that you would rend the heavens and come down': The eschatological theology of Third Isaiah (Isaiah 56-66), Pickwick Publications, Eugene, OR.

Richardson, A., 1958, An introduction to the theology of the New Testament, SCM Press, London.

Sailhamer, J., 1987, 'The canonical approach to the OT: Its effect on understanding prophecy', Journal of the Evangelical Theological Society 30, 307-315.

Schoeps, H.J., 1946, 'The Sacrifice of Isaac in Paul's theology', Journal of Biblical Literature 65, 385-392.

Schwartz, D.R., 1983, 'Two Pauline allusions to the redemptive mechanism of the crucifixion', Journal of Biblical Literature 102, 259-268.

Segal, A.F., 1984, 'He who did not spare his own son: Jesus, Paul, and the Akedah', in P. Richardson \& J.C. Hurd (eds.), From Jesus to Paul: Studies in honor of Francis Wright Beare, pp. 169-184, Wilfrid Laurier University Press, Waterloo.

Spiegel, S., 1979, The last trial: On the legend and lore of the command to Abraham to offer Isaac as a sacrifice, The Akedah, Behrman House, Inc, New York.

Swetnam, J., 1981, Jesus and Isaac: A study of the epistle to the Hebrews in the light of the Aqedah, Biblical Institute Press, Rome.

Vermes, G., 1961, 'Redemption and Genesis 22', in G. Vermes, Scripture and tradition in Judaism, pp. 193-227, E.J. Brill, Leiden.

Von Rad, G., 1961, Genesis. A commentary, OTL, J. Marks (transl.), Westminster, Philadelphia, PA.

Wenham, G.J., 1995, 'The Akedah: A paradigm of sacrifice', in D.P. Wright, D.N. Freedman \& A. Hurvitz (eds.), Pomegranates golden bells: Studies in Biblical,
Jewish, and Near Eastern ritual, law, and literature in honor of J. Milgrom, Jewish, and Near Eastern ritual, law, and
pp. 93-102, Eisenbrauns, Winona Lake, IN.

Westermann, C., 1984, Genesis I-II. A Commentary, (transl.) J.J. Scullion, Ausburg, Mineapolis, MN.

Wilken, R.L., 1976, 'Melito, the Jewish community at Sardis, and the sacrifice of Isaac', Theological Studies 37, 53-69.

Wood, J.E., 1968, 'Isaac typology in the New Testament', New Testament Studies 14 583-589.

Young, F., 1994, 'Typology', in S.E. Porter, P. Joyce \& D.E. Orton (eds.), Crossing the boundaries: Essays in Biblical interpretation, pp. 29-48, E.J. Brill, Leiden. 